\title{
Metabolic adjustments in two Amazonian cichlids exposed to hypoxia and anoxia
}

\author{
A.R. Chippari-Gomes ${ }^{\mathrm{a}, *}$, L.C. Gomes ${ }^{\mathrm{b}}$, N.P. Lopes $^{\mathrm{a}}$, A.L. Val ${ }^{\mathrm{a}}$, V.M.F. Almeida-Val ${ }^{\mathrm{a}}$ \\ ${ }^{a}$ Laboratory of Ecophysiology and Molecular Evolution, National Institute for Research in the Amazon (INPA), Manaus, Brazil \\ ${ }^{\mathrm{b}}$ Embrapa Amazônia Ocidental, Manaus, Brazil
}

Received 10 December 2004; received in revised form 18 April 2005; accepted 20 April 2005

\begin{abstract}
The effects of graded hypoxia on the physiological and biochemical responses were examined in two closely related species of cichlids of the Amazon: Astronotus crassipinnis and Symphysodon aequifasciatus. Ten fish of each species were exposed to graded hypoxia for $8 \mathrm{~h}$ in seven oxygen concentrations $\left(5.92,3.15,1.54,0.79,0.60,0.34\right.$, and $0.06 \mathrm{mg} \mathrm{O}_{2} \mathrm{~L}^{-1}$ ), with the aim to evaluate hypoxia tolerance and metabolic adjustments, where plasma glucose and lactate levels, hepatic and muscle glycogen contents, and maximum enzyme activities (PK, $\mathrm{LDH}, \mathrm{MDH}$ and $\mathrm{CS}$ ) in skeletal and cardiac muscles were measured. Another experimental set was done to quantify oxygen consumption $\left(\mathrm{MO}_{2}\right)$ and opercular movements in two oxygen concentrations. Hypoxia tolerance differed between the two species. Astronotus crassipinnis was able to tolerate anoxia for 178 min while $S$. aequifasciatus was able to withstand 222 min exposure in deep hypoxia $\left(0.75\right.$ mg $\left.\mathrm{O}_{2} \mathrm{~L}^{-1}\right)$. Suppressed $\mathrm{MO}_{2}$ was observed during exposure to 0.34 (A. crassipinnis) and $0.79 \mathrm{mg} \mathrm{O}_{2} \mathrm{~L}^{-1}$ ( $S$. aequifasciatus), while opercular movements increased in both species exposed to hypoxia. Higher levels of muscle and liver glycogen and larger hypoxia-induced increases in plasma glucose and lactate were observed in A. crassipinnis, which showed a higher degree of hypoxia tolerance. Changes in enzyme levels were tissue-specific and differed between species suggesting differential abilities in down-regulating oxidative pathways and increasing anaerobic metabolism. Based on the present data, we conclude that these animals are good anaerobes and highly adapted to their environment, which is allowed by their abilities to regulate metabolic pathways and adjust their enzyme levels.
\end{abstract}

(C) 2005 Elsevier Inc. All rights reserved.

Keywords: Amazonia; Astronotus crassipinnis; Symphysodon aequifasciatus; Oxygen depletion; Anaerobic metabolism; Metabolic suppression; Enzyme adjustments; Glycolysis

\section{Introduction}

Water oxygen levels are known to oscillate on a seasonal and diel basis in Amazonian waters (Junk, 1980) and these oscillations are thought to impact upon the distribution and abundance of fish (Junk et al., 1983; Crampton, 1996). Fish inhabiting these waters have developed adaptive strategies to survive low environmental oxygen (reviewed by Val and Almeida-Val, 1995) such as different modes of respiration

\footnotetext{
* Corresponding author. Instituto Nacional de Pesquisas da Amazônia, Laboratório de Ecofisiologia e Evolução Molecular, Avenida André Araújo, 2936, 69083-000, Manaus, AM, Brasil. Tel.: +55 92643 3187; fax: +55 92 6433186.

E-mail address: chippari@inpa.gov.br (A.R. Chippari-Gomes).
}

(obligatory and facultative air-breathing) and the use of aquatic surface respiration (ASR), a behavioral adjustment that allows fish to access oxygenated water from the waterair interface. As an alternative and/or complement to the morphological, behavioral and anatomical adaptations to hypoxia many vertebrates also use a combination of metabolic suppression and activation of anaerobic metabolism to survive periods of hypoxia, which has been referred to as "biochemical adaptations" (Hochachka and Somero, 2002).

Some Amazonian cichlids show remarkable tolerance of aquatic hypoxia (Almeida-Val et al., 1995; Chellapa et al., 1999) facilitated, in part, by biochemical adaptations that may be activated over the short term in response to spatial and temporal variation in dissolved oxygen. For instance, 
Astronotus ocellatus exposed to hypoxia without access to the surface suppresses metabolism at moderate hypoxia, while under severe hypoxia or anoxia, there is a partial compensation for energy production with the activation of anaerobic glycolysis (Muusze et al., 1998). Some cichlids are also able to regulate LDH isoforms (LDH- $\mathrm{A}_{4}$ and LDH$\mathrm{B}_{4}$ ) during exposure to hypoxia (Almeida-Val et al., 1995), which may permit access to or persistence in hypoxic waters.

Although some Amazonian cichlids seem highly tolerant of extreme hypoxia, there is variation within the group. This interspecific variation can be exploited in comparative studies to address the adaptive significance of metabolic adjustments during hypoxia exposure. In this study, we compare the effects of graded hypoxia on the physiological and biochemical responses of two closely related species of Amazonian cichlids: the oscar-Astronotus crassipinnis (Heckel), and the blue discus-Symphysodon aequifasciatus (Pellegrin). The species A. crassipinnis is very much like its congeneric $A$. ocellatus and both species are found in Amazonian floodplains and are known to survive periods of anoxia (Muusze et al., 1998, Almeida-Val et al., 1999, Almeida-Val et al., 2000). The other species, S. aequifasciatus, is found in small streams, rivers and lakes, among tangled roots and branches and is considered to be more sensitive to hypoxia than Astronotus species. No study has examined the hypoxia tolerance of $S$. aequifasciatus; however, our previous work examining LDH isozyme distribution in Amazonian fish suggests that their tissues are predominantly aerobic and, compared to other cichlid species, Symphysodon spp. are likely to have limited anaerobic capacity and thus potentially a limited ability to survive hypoxia (Almeida-Val et al., 1995).

Our specific objectives were to (1) quantify an index of hypoxia tolerance for the two species; and (2) quantify oxygen consumption $\left(\mathrm{MO}_{2}\right)$, opercular movements, plasma glucose and lactate levels, hepatic and muscle glycogen contents, organ somatic indexes, and maximum enzyme activities (PK, LDH, MDH and CS) of the two species in response to graded hypoxia.

\section{Materials and methods}

Two sets of experiments were done: the first was to evaluate hypoxia tolerance for the two species and their metabolic adjustments after $8 \mathrm{~h}$ of experiment. The second one was designed to quantify oxygen consumption $\left(\mathrm{MO}_{2}\right)$ and opercular movements for both species in two oxygen concentrations. Specimens of A. crassipinnis (43-67 g) and of $S$. aequifasciatus (24-32 g) were acquired from a local hatchery and from an ornamental fish exporter in Manaus, respectively. Fish were held indoors in 500-L fiberglass static holding tanks in the Laboratory of Ecophysiology and Molecular Evolution (INPA) for at least 20 days prior to experiments (35-45 fish/tank; two tanks per species). Water temperature and dissolved oxygen were monitored regularly and were maintained at $29^{\circ} \mathrm{C} \pm 0.5^{\circ} \mathrm{C}$ and $6.0 \mathrm{mg} \mathrm{O} \mathrm{L}^{-1}$ $(120 \mathrm{~mm} \mathrm{Hg}) ; 12 \mathrm{~L} / 12 \mathrm{D}$ cycle. Tanks were also equipped with glass wool filters to remove particulate material from water, and $50 \%$ water changes were performed every other day. Fish were fed commercial dry food pellets daily.

\subsection{Experiment 1: tolerance to low oxygen concentrations}

To assess hypoxia tolerance and evaluate metabolic consequences, 70 specimens of A. crassipinnis and 60 specimens of $S$. aequifasciatus were exposed to graded hypoxia. Individual fish were placed into a $15 \mathrm{~L}$ metabolic chamber without access to the surface, fitted with water inlet and outlet ports. Each chamber was immersed in a $100 \mathrm{~L}$ polystyrene box filled with water. Water was circulated from the outer polystyrene chamber through the metabolic chamber with a submersible pump, providing a closed flow-through system in order to control the chamber and surrounding water properties (Fig. 1). Fish were allowed to acclimate to normoxia in the metabolic chamber $\left(5.92 \pm 0.05 \mathrm{mg} \mathrm{O}_{2} \mathrm{~L}^{-1}-120 \mathrm{~mm} \mathrm{Hg}\right)$ for $12 \mathrm{~h}$ prior to experimentation. At the onset of the experiment, the oxygen concentration was decreased in a step-wise fashion from $5.92 \pm 0.05$, to $3.15 \pm 0.06,1.54 \pm 0.01$, $0.79 \pm 0.01,0.60 \pm 0.01,0.34 \pm 0.004$, and $0.06 \pm 0.01 \mathrm{mg}$ $\mathrm{O}_{2} \mathrm{~L}^{-1} \quad(n=10$ for each oxygen concentration). Final oxygen contents were obtained by bubbling $\mathrm{N}_{2}$ into the polystyrene container $(20 \%$ decrease per hour) and temperature was kept constant at $29{ }^{\circ} \mathrm{C} \pm 0.5{ }^{\circ} \mathrm{C}$. Fish were held at each oxygen level for $8 \mathrm{~h}$, and the loss of equilibrium indicated the lowest survivable oxygen level. Dissolved oxygen levels were continuously monitored using a dissolved oxygen meter YSI, model 85.

\subsubsection{Blood sampling and sample preparation}

After $8 \mathrm{~h}$ exposure to each oxygen concentration or until loss equilibrium $\left(0.60 \mathrm{mg} \mathrm{O}_{2} \mathrm{~L}^{-1}\right.$ for $S$. aequifasciatus and $0.06 \mathrm{mg} \mathrm{O}_{2} \mathrm{~L}^{-1}$ for A. crassipinnis), all fish were wrapped in towels to limit activity and a blood sample was immediately taken by caudal puncture. Immediately following blood sampling, animals were killed by concussion followed by spinal severance. Fish were weighted and tissues (liver, skeletal and heart muscles) were excised, promptly frozen in liquid nitrogen and stored at $-80{ }^{\circ} \mathrm{C}$ until enzyme and glycogen analyses were performed.

Plasma was obtained by blood centrifugation. Plasma glucose was promptly determined by end-point assays using enzymatic methods based on commercial kit (Doles $\left.{ }^{\circledR}\right)$. For lactate determination, plasma were acidified (PCA 8\%) and centrifuged, the supernatant was neutralized with $\mathrm{KOH} 6 \mathrm{M}$ and stored at $-80{ }^{\circ} \mathrm{C}$ until analyses. Lactate levels were determined with commercial kit (Sigma $\left.{ }^{\circledR}\right)$.

Skeletal muscle and liver glycogen concentrations were measured on frozen tissue as outlined by Bergmeyer (1974). Briefly, $100 \mathrm{mg}$ of frozen tissues was homogenized in 


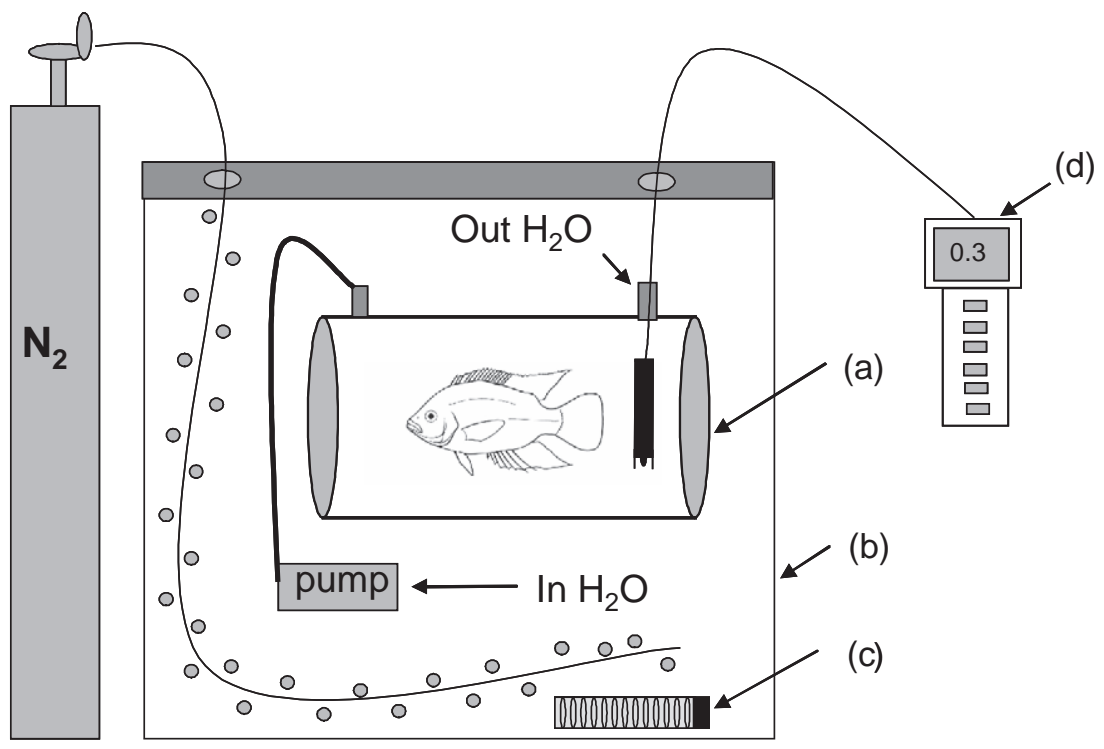

Fig. 1. Set up to analyze tolerance of hypoxia of A. crassipinnis and S. aequifasciatus (experiment 1). (a) Metabolic chamber-15 L; (b) Polystyrene box-100 L; (c) Temperature control; (d) Oxygen meter.

acetate buffer and glycogen digested with amyloglucosidase in a shaking chamber with temperature control (Technal, $\bmod \mathrm{TE} 420$ ) at $45^{\circ} \mathrm{C}$ during $4 \mathrm{~h}$. Glycogen was assayed as free glucose and expressed as $\mu$ moles of glycosyl units per gram of wet tissue ( $\mu \mathrm{mol}$ glycosyl $\mathrm{gwt}^{-1}$ ).

Activities of pyruvate kinase (PK; E.C. 2.7.40), lactate dehydrogenase (LDH; E.C. 1.1.1.27.), citrate synthase (CS; E.C. 4.1.3.7.) and malate dehydrogenase (MDH; E.C. 1.1.1.37) were estimated in skeletal muscle and heart according to techniques described in Driedzic and Almeida-Val (1996). For analysis of PK, LDH and MDH activities, samples were homogenized (Tissue Tearor mod. 985370) in a buffer containing $150 \mathrm{mM}$ imidazole, $1 \mathrm{mM}$ EDTA, $5 \mathrm{mM}$ dithiothreitol (DTT) and 1\% Triton X-100, $\mathrm{pH}$ 7.4. For CS activity, tissue samples were homogenized in a buffer containing $20 \mathrm{mM}$ HEPES, $1 \mathrm{mM}$ EDTA, with 1\% Triton X-100, $\mathrm{pH} 7.4$. Tissue/buffer ratios were 1:4 (w/ v) for skeletal muscle and 1:10 for heart muscle samples. To avoid loss of enzyme activity during sample preparation, procedures were performed on ice. Before analysis, homogenates were centrifuged at $13,000 \times \mathrm{g}$ for $10 \mathrm{~min}$ at $4{ }^{\circ} \mathrm{C}$.

Maximum activity levels were determined at $25^{\circ} \mathrm{C}$ using a Genesys 2 spectrophotometer. Pyruvate kinase, LDH and $\mathrm{MDH}$ enzyme activities were measured following the oxidation of NADH at $340 \mathrm{~nm}$ (mM extinction coefficient $=6.22$ ) and CS enzyme activities were based on the increase of free coenzyme A combined with DTNB $\left(5,5^{\prime}\right.$ dithio-bis(2-nitrobenzoic acid)) at $412 \mathrm{~nm}$ (mM extinction coefficient $=13.6)$.

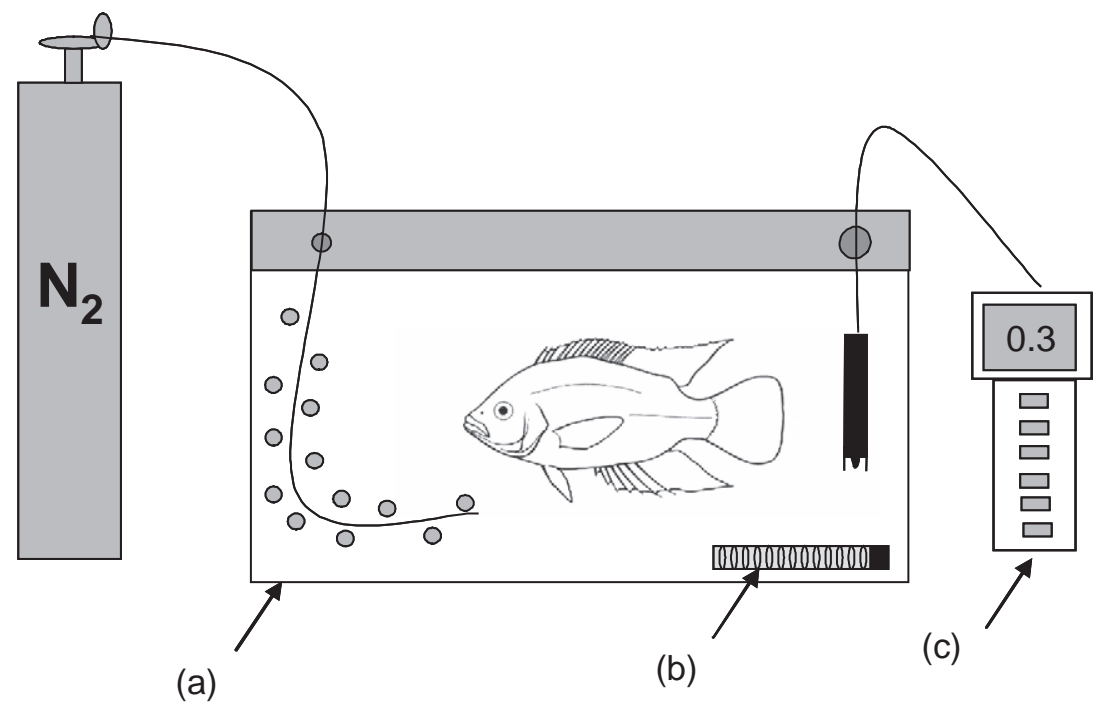

Fig. 2. Set up to analyze $\mathrm{MO}_{2}$ and opercular movements of A. crassipinnis and S. aequifasciatus (experiment 2). (a) Pespex aquaria-6 L; (b) Temperature control; (c) Oxygen meter. 
All assay conditions were based on well-established protocols for fish tissues (Moon and Mommsen, 1987; Sidell et al., 1987; Singer and Ballantyne, 1989). Pyruvate kinase was assayed in a solution containing $150 \mathrm{mM} \mathrm{KCl}$, $0.15 \mathrm{mM} \mathrm{NADH}, 5 \mathrm{mM}$ ADP, $10 \mathrm{IU} / \mathrm{ml}$ of lactate dehydrogenase, $1 \mathrm{mM} \mathrm{KCN}$ and $50 \mathrm{mM}$ imidazole, $\mathrm{pH}$ 6.9 at $25^{\circ} \mathrm{C}$. The reactions were initiated by adding $2.5 \mathrm{mM}$ phosphoenolpyruvate (PEP). Lactate dehydrogenase was assayed in a medium containing $0.15 \mathrm{mM}$ NADH, $1 \mathrm{mM}$ $\mathrm{KCN}$ and $50 \mathrm{mM}$ imidazole, $\mathrm{pH} 7.4$ at $25^{\circ} \mathrm{C}$. The reactions were initiated by adding $1 \mathrm{mM}$ pyruvate. Citrate synthase was assayed in a medium containing $0.4 \mathrm{mM}$ acetyl CoA, $0.25 \mathrm{mM}$ DTNB and $75 \mathrm{mM}$ Tris buffer, $\mathrm{pH} 8.0$ at $25{ }^{\circ} \mathrm{C}$. The reactions were initiated by adding $0.5 \mathrm{mM}$ oxaloacetate (OAA). Malate dehydrogenase was assayed in a medium containing $0.15 \mathrm{mM} \mathrm{NADH}, 1 \mathrm{mM} \mathrm{KCN}$ and $50 \mathrm{mM}$ imidazole, $\mathrm{pH} 7.4$ at $25^{\circ} \mathrm{C}$. The reactions were initiated by adding $0.5 \mathrm{mM}$ OAA. Enzyme activities are expressed as $\mu$ mols of substrate $\min ^{-1} \mathrm{~g}$ wet tissue ${ }^{-1}$. All assays were conducted on diluted or crude homogenates.

\subsection{Experiment 2: oxygen consumption rates and opercular movements}

Another system was used to measure $\mathrm{MO}_{2}$ and opercular movements in fish exposed to hypoxia. This set up consisted of four sealed Perspex (Plexiglass) aquaria $(6.0 \mathrm{~L})$ fitted with an aeration system and held at a constant temperature of $29^{\circ} \mathrm{C} \pm 0.5^{\circ} \mathrm{C}$ (Fig. 2). Twelve fish of each species were exposed individually to two oxygen levels without access to the surface: normoxic $(n=6)$ and the lowest hypoxic condition $\left(0.79 \mathrm{mg} \mathrm{O}_{2} \mathrm{~L}^{-1}\right.$ for $S$. aequifasciatus and 0.34 $\mathrm{mg} \mathrm{O}_{2} \mathrm{~L}^{-1}$ for $A$. crassipinnis - see results) each species survived for the full $8 \mathrm{~h}$ exposure $(n=6)$. Fish were exposed to graded hypoxia as described above and once the desired water oxygen levels were reached, $\mathrm{MO}_{2}$ and opercular movements were measured at $0,2,4,6$ and $8 \mathrm{~h}$. For each measurement, the chamber was sealed, and four oxygen concentration measurements were taken at 10 min intervals using the YSI oxygen meter. Oxygen consumption was calculated from the difference in water oxygen content over the $10 \mathrm{~min}$ interval and is expressed as $\mathrm{mg} \mathrm{O}_{2} \mathrm{~g}^{-1} \mathrm{~h}^{-1}$. Direct counts of the opercular movements were made during $1 \mathrm{~min}$ and opercular movements are expressed as number of opercular movements per minute.

\subsection{Statistical analysis}

The results are expressed as means \pm S.E.M. Statistical differences among experimental groups (different hypoxia degrees) were analyzed with a one-way analysis of variance followed by Dunnett's test. Oxygen consumption and opercular movements in both species exposed to normoxia and hypoxia were analyzed with a two-way analysis of variance followed by Tukey's multiple comparisons test. Significant differences were accepted when $P<0.05$.

\section{Results}

Astronotus crassipinnis survived $8 \mathrm{~h}$ exposure to each of the sequentially tested oxygen concentrations, losing equilibrium after $178 \pm 27.4 \mathrm{~min}(2.96 \mathrm{~h})$ of exposure to anoxia. $S$. aequifasciatus tolerated $8 \mathrm{~h}$ exposure to all oxygen concentrations down to $0.79 \mathrm{mg} \mathrm{O} \mathrm{O}^{-1}$, and lost equilibrium after $222 \pm 56.4 \mathrm{~min}(3.69 \mathrm{~h})$ exposure to 0.60 $\mathrm{mg} \mathrm{O}_{2} \mathrm{~L}^{-1}$. Suppressed $\mathrm{MO}_{2}$ was observed during exposure to 0.34 and $0.79 \mathrm{mg} \mathrm{O}_{2} \mathrm{~L}^{-1}$ for A. crassipinnis and $S$. aequifasciatus, respectively (Fig. 3A and B). The $\mathrm{MO}_{2}$ of $S$. aequifasciatus was significantly lower in $2 \mathrm{~h}$ of exposure at normoxia compared to 6 and $8 \mathrm{~h}$, and significantly lower in $4 \mathrm{~h}$ of exposure at normoxia compared to $8 \mathrm{~h}$. Astronotus crassipinnis did not show any significant alterations during $8 \mathrm{~h}$ of exposure in both conditions. Opercular movements increased in both species exposed to hypoxia (Fig. 4). It is interesting to note that opercular movements of $S$. aequifasciatus were higher than $A$. crassipinnis in both normoxia and hypoxia, suggesting a lower efficiency in oxygen extraction in the former, compared to the latter.
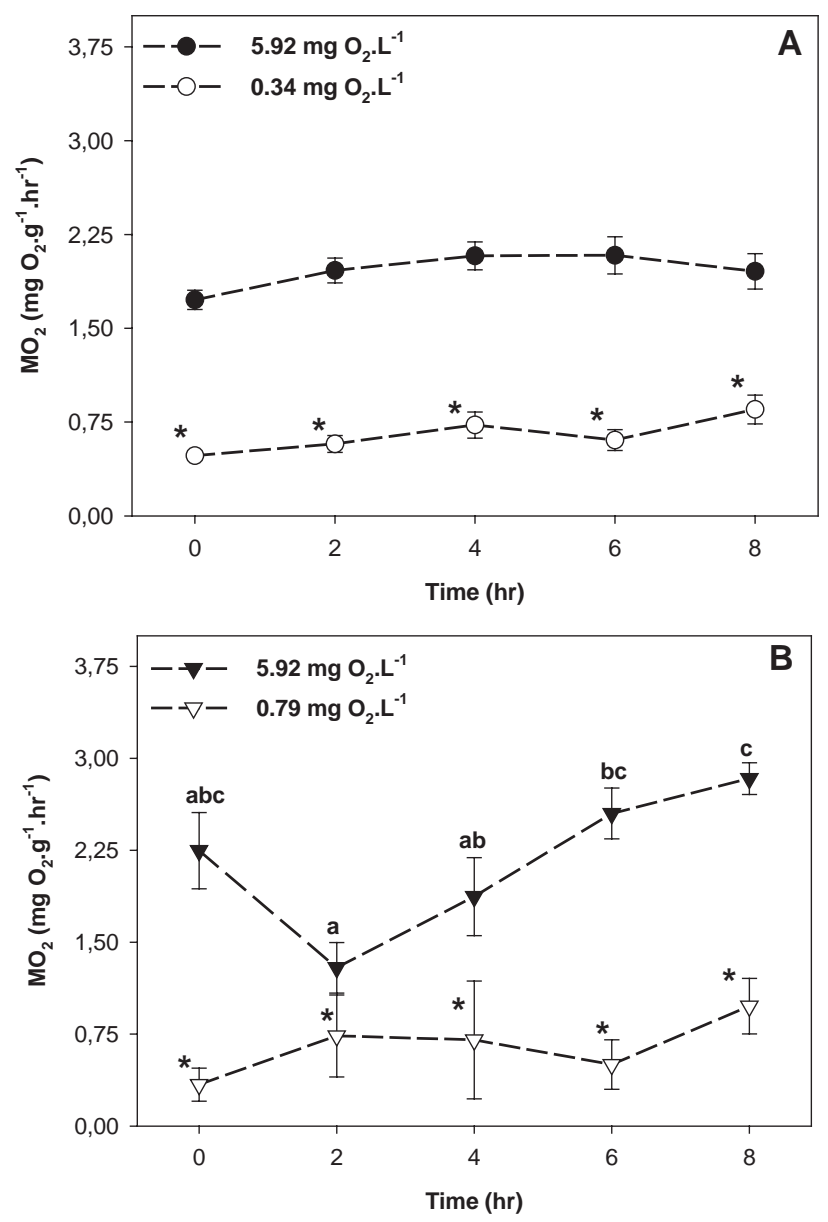

Fig. 3. $\mathrm{MO}_{2}$ of A. crassipinnis (A) and S. aequifasciatus (B) exposed to normoxia and hypoxia for $8 \mathrm{~h}(n=6$, mean \pm S.E.M. $) .{ }^{*}$ indicates values significantly different from normoxia $\left(5.92 \mathrm{mg} \mathrm{O}_{2} \mathrm{~L}^{-1}\right)(P<0.05)$. Different letters indicate significant difference $(P<0.05)$ under normoxia for $S$. aequifasciatus. 

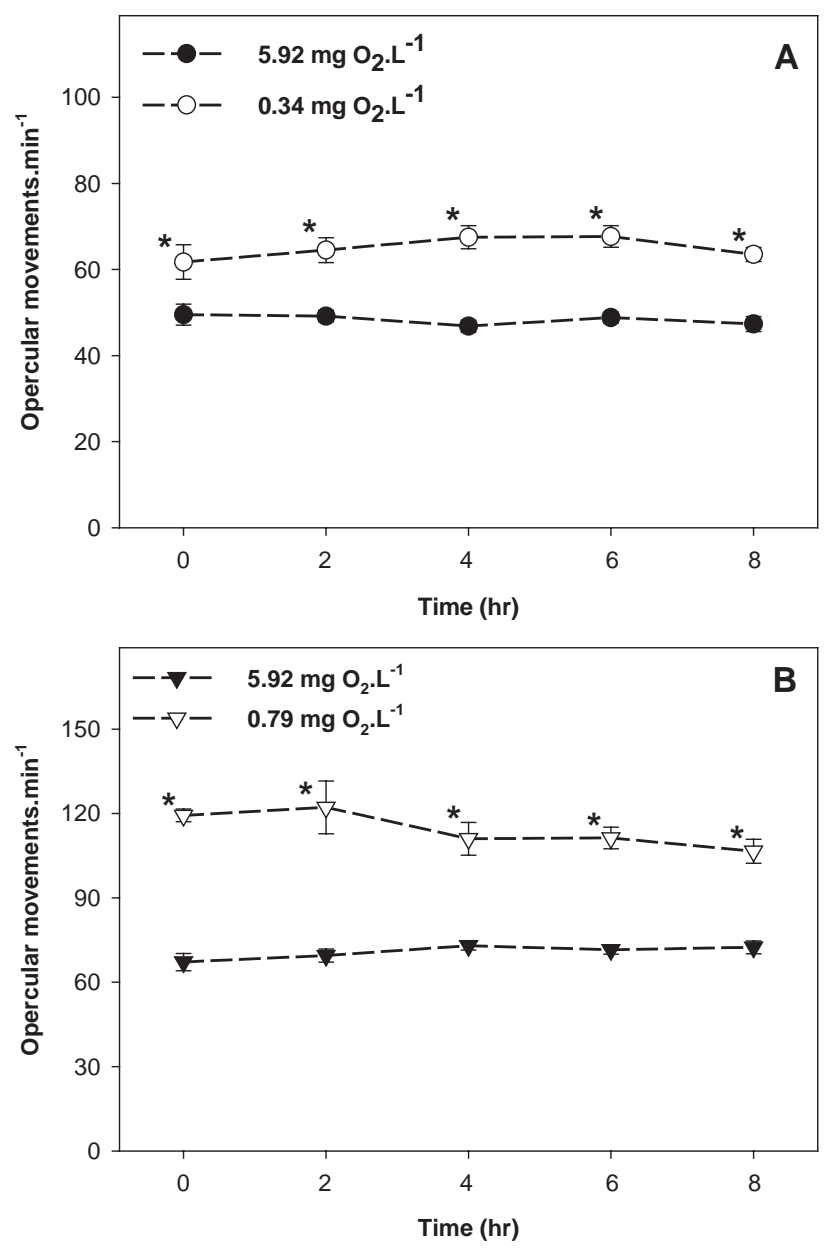

Fig. 4. Opercular movements of A. crassipinnis (A) and S. aequifasciatus (B) exposed to normoxia and hypoxia for $8 \mathrm{~h}(n=6$, mean \pm S.E.M.). * indicates values significantly different from normoxia $\left(5.92 \mathrm{mg} \mathrm{O}_{2} \mathrm{~L}^{-1}\right)$ $(P<0.05)$.

Glucose concentrations were different in normoxia acclimated fish; plasma glucose was higher in A. crassipinnis compared to $S$. aequifasciatus. A maximum plasma glucose concentration of $93.6 \mathrm{mg} \mathrm{dL}^{-1}$ was observed in $S$. aequifasciatus following $3.68 \mathrm{~h}$ exposure at $0.6 \mathrm{mg} \mathrm{O}_{2} \mathrm{~L}^{-1}$ and a maximum of $233.9 \mathrm{mg} \mathrm{dL}^{-1}$ in $A$. crassipinnis after $2.96 \mathrm{~h}$ exposed to anoxia (Fig. 5A). Plasma lactate concentrations were not different between the two species in normoxic water, but following exposure to $8 \mathrm{~h}$ of $0.79 \mathrm{mg}$ $\mathrm{O}_{2} \mathrm{~L}^{-1}$ a maximum of $7.6 \mathrm{mM}$ in $S$. aequifasciatus and $18.5 \mathrm{mM}$ in A. crassipinnis was reached (Fig. 5B).

Liver and muscle glycogen contents were higher in $A$. crassipinnis than $S$. aequifasciatus kept in normoxic water (Fig. 6A and B). The hepatosomatic index (relative liver size) of $A$. crassipinnis was also significantly $(P<0.001)$ higher than $S$. aequifasciatus $(2.543 \pm 0.154$ and $0.609 \pm 0.034$, respectively). Mobilization of liver glycogen in response to hypoxia exposure occurred in both species (Fig. 6A), but the magnitude of the mobilization differed between them. Specifically, liver glycogen remained elevated in $A$. crassipinnis until $0.34 \mathrm{mg} \mathrm{O}_{2} \mathrm{~L}^{-1}$ then dropped following $2.96 \mathrm{~h}$ exposure to anoxia. In $S$. aequifasciatus, liver glycogen decreased after exposure to severe hypoxia. In contrast to the changes observed in liver glycogen, muscle glycogen increased in both species following exposure to hypoxia (Fig. 6B).

Almost all enzyme activities differed between species under normoxia. In muscle, $A$. crassipinnis had significantly higher PK and MDH activities than $S$. aequifasciatus (Figs. $7 \mathrm{~A}$ and $8 \mathrm{C}$ ). In heart, $\mathrm{PK}$ activity was higher in $A$. crassipinnis compared to $S$. aequifasciatus (Fig. 8A), and $\mathrm{LDH}$ activity was higher in $S$. aequifasciatus (Fig. 8B). Muscle LDH activity in $A$. crassipinnis decreased after exposure to 3.15 and $1.54 \mathrm{mg} \mathrm{O}_{2} \mathrm{~L}^{-1}$ relative to normoxia; however, LDH levels returned to levels characteristic of normoxia when dissolved oxygen was lower than $0.79 \mathrm{mg} \mathrm{O}_{2}$ $\mathrm{L}^{-1}$ (Fig. 7B). In contrast, muscle LDH activities decreased in $S$. aequifasciatus exposed to $1.54 \mathrm{mg} \mathrm{O}_{2} \mathrm{~L}^{-1}$ and remained suppressed in animals exposed to lower oxygen concentrations (Fig. 7B). Muscle $\mathrm{MDH}$ activity decreased after exposure to $3.15 \mathrm{mg} \mathrm{O}_{2} \mathrm{~L}^{-1}$ and remained low at all levels of hypoxia in $A$. crassipinnis, suggesting a depression of non-
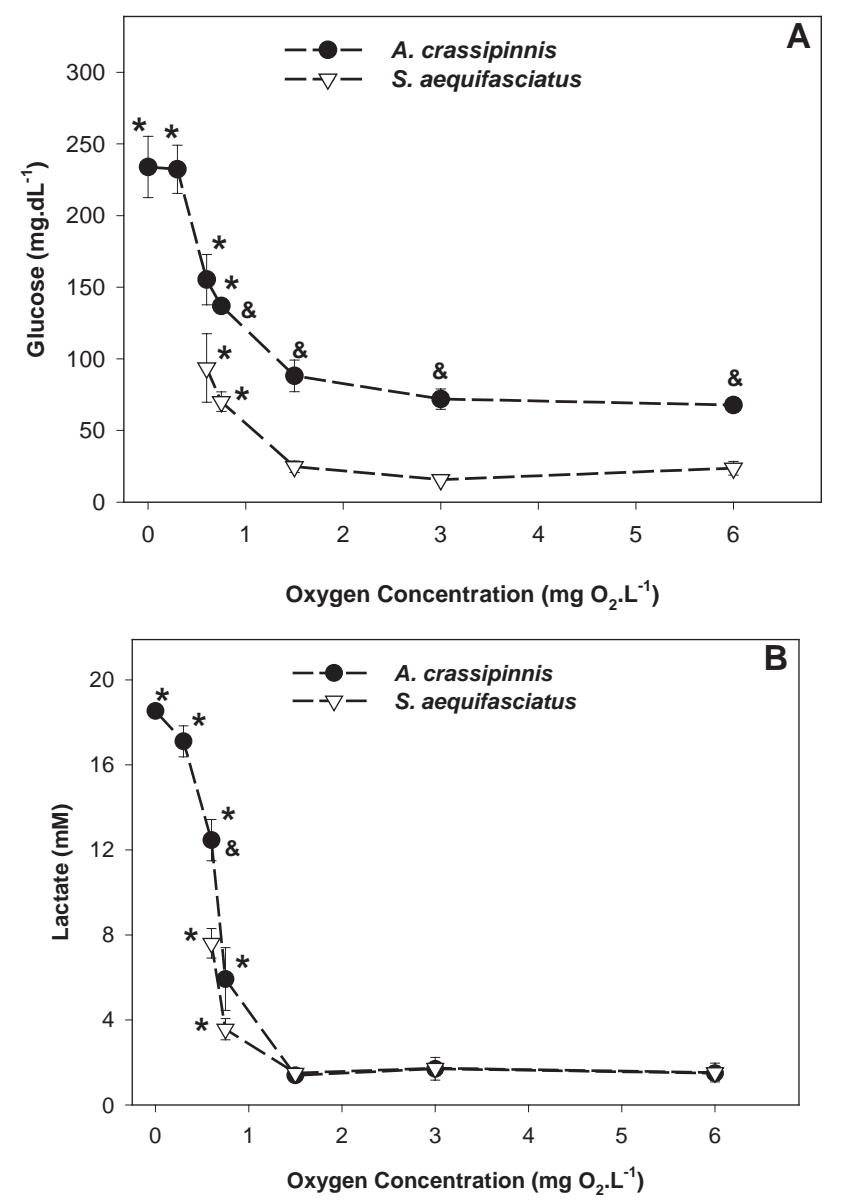

Fig. 5. Plasma glucose (A) and lactate (B) in A. crassipinnis and $S$. aequifasciatus exposed to graded hypoxia for $8 \mathrm{~h}(n=10$, mean \pm S.E.M.). * indicates values significantly different from normoxia $\left(5.92 \mathrm{mg} \mathrm{O}_{2} \mathrm{~L}^{-1}\right.$ ) $(P<0.05) .{ }^{\&}$ represents significant difference between $A$. crassipinnis and S. aequifasciatus $(P<0.05)$. 

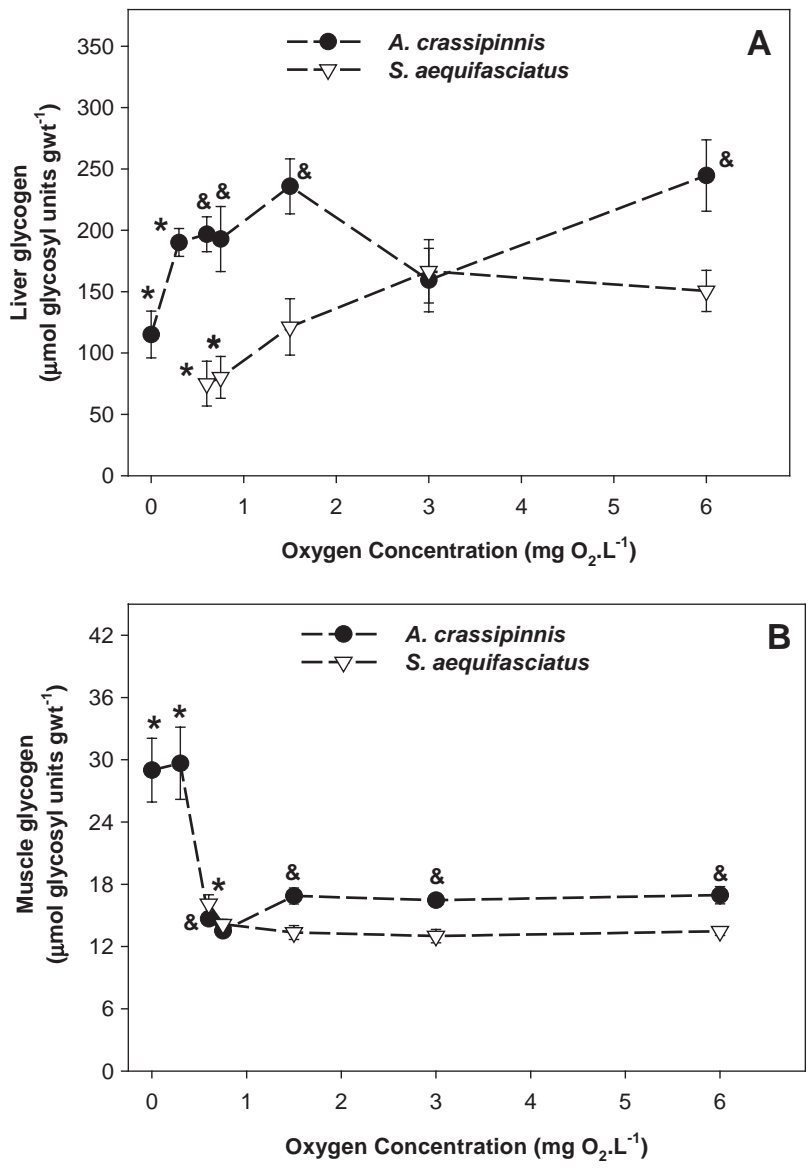

Fig. 6. Hepatic glycogen (A) and muscle glycogen (B) of A. crassipinnis and $S$. aequifasciatus exposed to graded hypoxia for $8 \mathrm{~h}(n=10$, mean \pm S.E.M.). * indicates values significantly different from normoxia (5.92 $\left.\mathrm{mg} \mathrm{O}_{2} \mathrm{~L}^{-1}\right)(P<0.05) .{ }^{\&}$ represents significant difference between $A$. crassipinnis and $S$. aequifasciatus $(P<0.05)$.

glycolytic pathways (Fig. 7C). On the other hand, muscle MDH activity was not affected by hypoxia in $S$. aequifasciatus (Fig. 7C). Exposure to $3.15 \mathrm{mg} \mathrm{O}_{2} \mathrm{~L}^{-1}$ caused a transient decrease in muscle PK in A. crassipinnis followed by a recovery to normoxic levels at lower oxygen concentrations: 1.54 to $0.34 \mathrm{mg} \mathrm{O}_{2} \mathrm{~L}^{-1}$. Exposure to anoxia, however, caused a decrease in muscle PK compared to normoxic values (Fig. 7A). In S. aequifasciatus, hypoxia exposure did not affect muscle PK activities, which under most conditions were lower than A. crassipinnis (Fig. 7A).

Heart PK activity decreased in A. crassipinnis upon exposure to water oxygen levels lower than $0.6 \mathrm{mg} \mathrm{O}_{2} \mathrm{~L}^{-1}$ (Fig. 8A), but were unaltered in S. aequifasciatus. On the other hand, heart LDH activities increased significantly in both species when exposed to oxygen concentrations lower than $0.79 \mathrm{mg} \mathrm{O}_{2} \mathrm{~L}^{-1}$ (Fig. 8B). Exposure to increasing levels of hypoxia had no effect on heart MDH activity in either species (Fig. 8C). Heart CS activities decreased in both species exposed to hypoxia and anoxia (Fig. 8D).

Enzyme activities ratios were also calculated (PK/LDH, $\mathrm{MDH} / \mathrm{LDH}$ and $\mathrm{CS} / \mathrm{LDH}$ ) for skeletal and cardiac muscles (Table 1), with the aim to indicate which type of metabolism is preferred by the organism. Most results were compatible with the predominance of anaerobic metabolism in muscle and heart of both species after hypoxia and anoxia exposure (Table 1). Heart metabolism differ in both species mostly due to the increased LDH levels occurring in $S$. aequifasciatus, reflecting CS/LDH
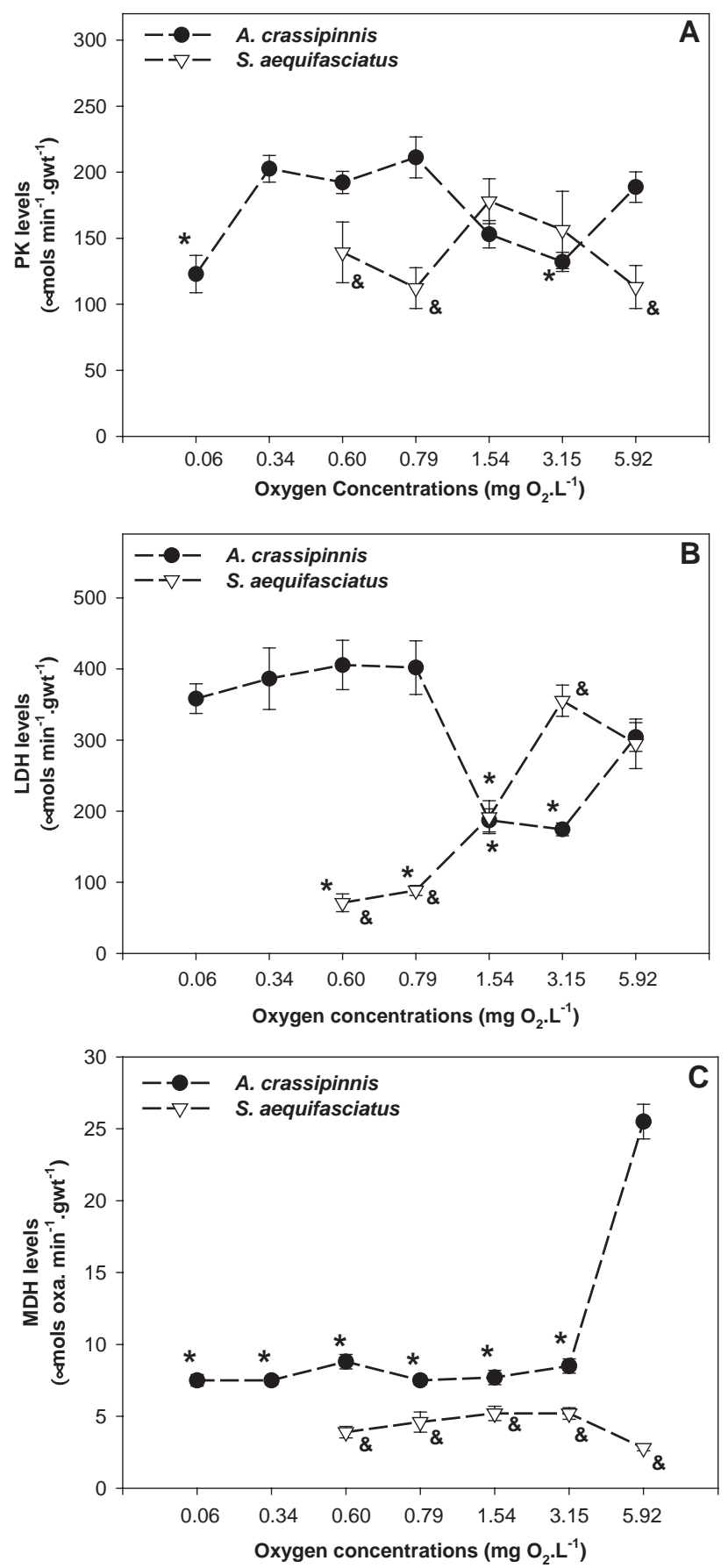

Fig. 7. Enzyme activities of pyruvate kinase (A), lactate dehydrogenase (B) and malate dehydrogenase (C) in skeletal muscle of $A$. crassipinnis and $S$. aequifasciatus after $8 \mathrm{~h}$ of exposure to each of oxygen concentrations (mean \pm S.E.M., $n=10$ ). * indicates values significantly different from normoxia $\left(5.92 \mathrm{mg} \mathrm{O}_{2} \mathrm{~L}^{-1}\right)(P<0.05) .{ }^{\&}$ represents significant difference between $A$. crassipinnis and $S$. aequifasciatus $(P<0.05)$. 

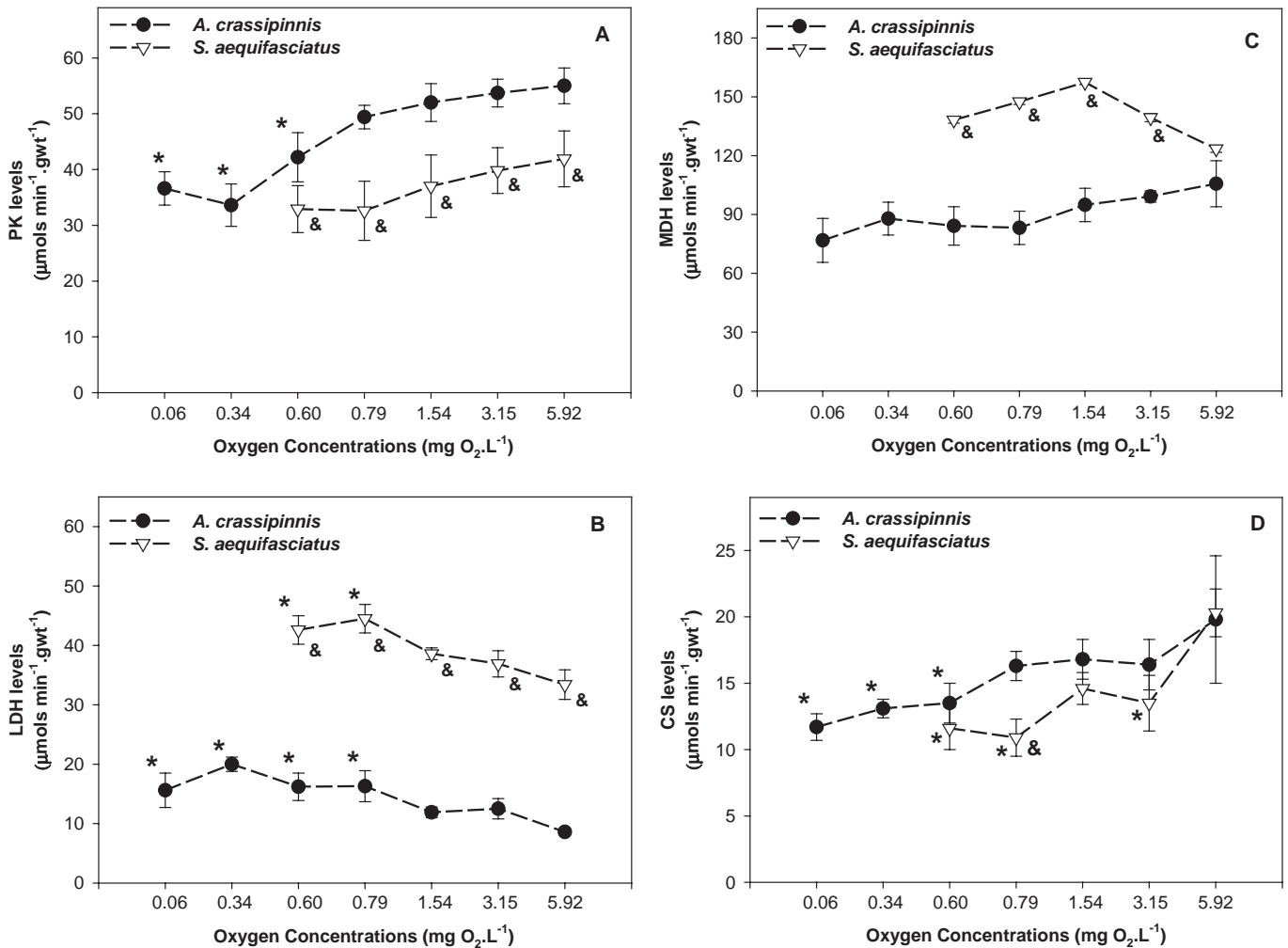

Fig. 8. Enzyme activities of pyruvate kinase (A), lactate dehydrogenase (B), malate dehydrogenase (C) and citrate synthase (D) in cardiac muscle of $A$. crassipinnis and $S$. aequifasciatus after $8 \mathrm{~h}$ of exposure to each of oxygen concentrations (mean \pm S.E.M., $n=10) . *$ indicates values significantly different from normoxia $\left(5.92 \mathrm{mg} \mathrm{O}_{2} \mathrm{~L}^{-1}\right)(P<0.05)$. ${ }^{\&}$ represents significant difference between A. crassipinnis and $S$. aequifasciatus $(P<0.05)$.

ratios lower than 1.0. On the other hand, A. crassipinnis heart is predominantly oxidative during most part of experiment, becoming anaerobically oriented when exposed to oxygen levels lower than $0.60 \mathrm{mg} \mathrm{O}_{2} \mathrm{~L}^{-1}$, mostly due to a deeper decrease in CS levels, rather than the small increase in LDH. A similar trend is observed in $S$. aequifasciatus which heart presents much higher LDH levels during all experimental procedure compared with $A$. crassipinnis. Considering the overall picture, and based on the whole set of results, we can conclude that $A$. crassipinnis is more tolerant of hypoxia than $S$. aequifasciatus, as we shall discuss next.

Table 1

Enzyme ratios in skeletal and heart muscles of A. crassipinnis and S. aequifasciatus after $8 \mathrm{~h}$ of exposure to each oxygen concentrations: $5.92,3.15,1.54,0.79$, $0.60,0.34$ and $0.06 \mathrm{mg} \mathrm{O}_{2} \mathrm{~L}^{-1}$

\begin{tabular}{|c|c|c|c|c|c|}
\hline \multirow[t]{2}{*}{$\mathrm{O}_{2}$ Levels } & \multicolumn{2}{|l|}{ Muscle } & \multicolumn{3}{|l|}{ Heart } \\
\hline & $\mathrm{PK} / \mathrm{LDH}$ & MDH/LDH & PK/LDH & MDH/LDH & $\mathrm{CS} / \mathrm{LDH}$ \\
\hline \multicolumn{6}{|c|}{ A. crassipinnis } \\
\hline 5.92 & $0.624(0.150)$ & $0.087(0.006)$ & $6.693(0.323)$ & $13.266(1.406)$ & $2.308(0.181)$ \\
\hline 3.15 & $0.768(0.046)$ & $0.049 *(0.003)$ & $5.341(1.021)$ & 9.874 (1.844) & $1.760(0.484)$ \\
\hline 1.54 & $0.844(0.061)$ & $0.041 *(0.003)$ & $4.559(0.402)$ & $8.535 *(1.448)$ & $1.501 *(0.186)$ \\
\hline 0.79 & $0.568(0.052)$ & $0.022 *(0.003)$ & $3.574 *(0.630)$ & $6.736 *(1.298)$ & $1.102 *(0.162)$ \\
\hline 0.60 & $0.489 *(0.023)$ & $0.023 *(0.002)$ & $2.963 *(0.582)$ & $6.460 *(1.197)$ & $0.913 *(0.170)$ \\
\hline 0.34 & $0.613(0.074)$ & $0.022 *(0.002)$ & $1.992 *(0.181)$ & $4.892 *(0.665)$ & $0.672 *(0.064)$ \\
\hline 0.06 & $0.363 *(0.063)$ & $0.022 *(0.002)$ & $2.905 *(0.581)$ & $7.914 *(2.090)$ & $0.934 *(0.202)$ \\
\hline \multicolumn{6}{|c|}{ S. aequifasciatus } \\
\hline 5.92 & $0.405(0.096)$ & $0.009(0.001)$ & $1.387(0.158)$ & $4.177(0.497)$ & $0.645(0.053)$ \\
\hline 3.15 & $0.428(0.066)$ & $0.015(0.001)$ & $1.119(0.163)$ & $4.000(0.560)$ & $0.375 *(0.060)$ \\
\hline 1.54 & $1.036(0.129)$ & $0.032 *(0.006)$ & $0.976(0.159)$ & $4.110(0.434)$ & $0.382 *(0.032)$ \\
\hline 0.79 & $1.348(0.228)$ & $0.053 *(0.008)$ & $0.781(0.135)$ & $3.450(0.308)$ & $0.265 *(0.037)$ \\
\hline 0.60 & $3.292 *(1.360)$ & $0.070 *(0.019)$ & $0.765(0.098)$ & $3.198(0.290)$ & $0.273 *(0.035)$ \\
\hline
\end{tabular}

Data are expressed as mean and S.E.M. (in branches), $n=10$. Asterisks indicate significant difference $(P<0.05)$ from normoxic exposed animals. 


\section{Discussion}

The goal of the present work was to investigate the metabolic responses and enzyme adjustments of two cichlid species to better understand the mechanism that may account for differences in hypoxia tolerance. The two species differed in their hypoxia tolerance as demonstrated by the ability of $A$. crassipinnis to remain vertical for almost $3 \mathrm{~h}$ exposure to anoxia, while $S$. aequifasciatus lost equilibrium after only $3.5 \mathrm{~h}$ exposed to $0.60 \mathrm{mg} \mathrm{O}_{2} \mathrm{~L}^{-1}$ without access to the surface. The greater hypoxia tolerance in A. crassipinnis is due, at least in part, to the higher concentrations of liver and muscle glycogen. Although both species showed similar responses to hypoxia: decreasing $\mathrm{MO}_{2}$, increasing opercular movements and activating anaerobic glycolysis (evidenced by accumulation of plasma lactate), the more hypoxia tolerant specie, A. crassipinnis, accumulated lactate at a higher rate than $S$. aequifasciatus and ultimately accumulated higher concentrations of plasma glucose. In fact, although LDH levels accounted for a higher anaerobic rate in $S$. aequifasciatus's heart, it is clearly higher in $A$. crassipinnis muscle at oxygen levels lower than $0.79 \mathrm{mg} \mathrm{O}_{2} \mathrm{~L}^{-1}$, certainly contributing to the accumulation of lactate plasma. The higher accumulation of plasma glucose in A. crassipinnis at low oxygen levels was likely due to an activation of hepatic glycogenolysis as indicated by the decrease in liver glycogen, which was probably canalized to anaerobic glycolysis in muscle, shown by increase in PK. It is important to clarify that these results were obtained from fishes acclimated during 20 days in normoxic water and the experiment was realized in a system without access to the surface, which may suggest more intensive responses than in nature.

The reduction in liver glycogen for both species when exposed to deep hypoxia indicates that glycogen is an important glucose energy source as reported elsewhere by Van den Thillart and Van Raaij (1995). In general, hypoxiatolerant species are able to survive long periods of oxygen depletion through anaerobic utilization of enormous glycogen reserves found in the red muscle, heart and liver (Driedzic et al., 1978; Hochachka et al., 1978). Our data explicitly supports this statement since $A$. crassipinnis has higher liver and muscle glycogen and is more hypoxia tolerant than $S$. aequifasciatus. Also, the relative size of their livers is indicative of such differences.

Another intriguing result is the accumulation in muscle glycogen in both species at relatively severe levels of hypoxia. There are two possible explanations for the hypoxia-induced increase in muscle glycogen. First, glycogen accumulation in muscle during exposure to hypoxia could be accounted for by shuttling of glucose from liver glycogen to the muscle for glycogen synthesis. Second, the accumulation of muscle glycogen during exposure to hypoxia maybe due to the activation of muscle gluconeogenesis; however, this seems unlikely due to its high energy costs (6 ATPs for unit of glycosyl). Further investigations with labeled glucose and other enzyme measurements (glycogen synthase, phosphoenolpyruvate carboxykinaseHochachka et al., 1997) are needed to better understand the mechanism and utility of muscle glycogen accumulation during severe hypoxia.

Changes in enzyme activities in response to hypoxia differed between the two cichlids and were tissue specific. Muscle MDH from $A$. crassipinnis displayed a significant decrease during hypoxia, while LDH and PK presented decreased values at moderate hypoxia and reestablished control levels when exposed to severe hypoxia. These results suggest that $A$. crassipinnis adjusts its metabolism toward efficient anaerobic production of ATP and the use of LDH to maintain cytoplasmic NAD/NADH (i.e. higher LDH activity relative to both PK and MDH activities), while S. aequifasciatus adjusts its enzyme levels to limit lactate production and enhance aerobic maintenance of cytoplasmic NAD/NADH. These results relate well to the differential capacity of each species to activate glycolysis and ultimately survive hypoxia and point to adjustments of anaerobic capacity as a key feature to enhanced hypoxia tolerance.

For heart, LDH activity increased during hypoxia in both species, suggesting an activation of anaerobic metabolism. However, we also observed that heart LDH levels in $A$. crassipinnis were 3 times lower compared to $S$. aequifasciatus under normoxic conditions. To our knowledge, heart LDH activities of $A$. crassipinnis are the lowest values described in fish. West et al. (1999) found $256 \mu \mathrm{mol} \mathrm{min}^{-1}$

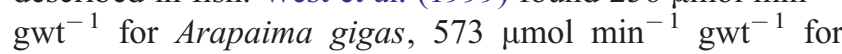
rainbow trout; Driedzic and Almeida-Val (1996) found 81

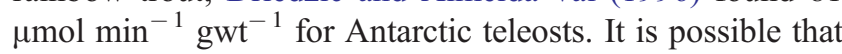
these $\mathrm{LDH}$ values are related to the muscle type isozyme that is predominant in cichlids (Almeida-Val et al., 1995). The decrease in heart-type LDH with concomitant replacement with muscle-type LDH in hearts has been described in A. ocellatus and other species. Muscle type LDH predominates in $A$. crassipinnis hearts and pyruvate inhibition rates are absent in all experimental conditions (Chippari-Gomes, 2002), suggesting the activation of anaerobic glycolysis when pyruvate accumulates due to a decrease in oxidative metabolism. In fact, there is a concomitant increase in heart LDH levels with the decrease in heart CS levels in animals exposed to hypoxia and anoxia. As already stated, these changes are more accentuated in S. aequifasciatus, and this is better understood when we consider the much higher ability of $A$. crassipinnis in producing ATP at the expenses of anaerobic metabolism in skeletal muscle, which is the predominant tissue in these species.

The changes in LDH and CS in heart of A. crassipinnis and $S$. aequifasciatus, as hypoxia becomes more severe, suggest a shift to the anaerobic metabolism in this organ. Thus, the heart of these animals undergoes suppression of oxidative metabolism followed by the activation of anaerobic glycolysis. This response has usually been observed in the so-called "good anaerobes", such as the aquatic turtles and other fish species (Hochachka and Somero, 1984). 
From the present results, we may summarize the main conclusions as follows: (i) there is a combination of both metabolic suppression and anaerobic pathway in response to graded hypoxia for both cichlids; and (ii) these responses differ in intensity between the two species. A moderate tolerance to graded hypoxia is observed in S. aequifasciatus, while $A$. crassipinnis presents much higher tolerance. As a consequence of such higher tolerance, A. crassipinnis may have a broader ecological scope and explore habitats where food and nutrients are more available, where hypoxia is common, e.g. floodplain areas. These responses may be the result of the adaptive process this species has undergone through its evolutionary history. On the other hand, the lower hypoxia tolerance of $S$. aequifasciatus also reflects its habitats preferences since $S$. aequifasciatus is preferentially found in small streams, and other well oxygenated places. In summary, the biochemical and physiological strategies presented by these two cichlids, activated at a short-term period of time, may permit the flexibility to deal with temporal and spatial variation in dissolved oxygen which is a characteristic of most Amazonian aquatic habitats.

\section{Acknowledgments}

The present work was supported by an internal grant from the National Institute for Research in the Amazon (INPA grant number 1-3140). The Brazilian National Research Council funded the Hypoxia Research Program providing the grant number 400030/99-3, a Ph.D. Scholarship to A.R.C.G. (CNPq) and two Research Fellowships to A.L.V. and V.M.F.A.V (procs. 3065442/2003-0 and 350505/1993-4, respectively). We thank Jeff G. Richards and Tyson MacCormack for helpful comments on the manuscript. We also thank Carlos Edwar C. Freitas for his helpful aid in the statistic data analysis. The comments of two anonymous reviewers were appreciated.

\section{References}

Almeida-Val, V.M.F., Farias, I.P., Paula-Silva, M.N., Duncan, W.P., 1995. Biochemical adjustments to hypoxia by (cf) Amazon Cichlids. Braz. J. Med. Biol. Res. 28, 1257-1263.

Almeida-Val, V.M.F., Paula-Silva, M.N., Duncan, W.P., Lopes, N.P., Val, A.L., Land, S., 1999. Increase of anaerobic potential during growth of an Amazonian cichlid, Astronotus ocellatus. Survivorship and LDH regulation after hypoxia exposure. In: Val, A.L., Almeida-Val, V.M.F. (Eds.), Biology of Tropical Fishes. INPA, Manaus, pp. 437-448.

Almeida-Val, V.M.F., Val, A.L., Duncan, W.P., Souza, F.C.A., PaulaSilva, M.N., Land, S., 2000. Scaling effects on hypoxia tolerance in the Amazon fish Astronotus ocellatus (Perciformes: Cichlidae): contribution of tissue enzyme levels. Comp. Biochem. Physiol., B 125, 219-126.4.
Bergmeyer, H.U., 1974. Methods of Enzymatic Analysis. Academic Press, New York.

Chellapa, S., Yamamoto, M.E., Cacho, M.S.R.F., 1999. Reproductive behavior and ecology of two species of cichlid fishes. In: Val, A.L., Almeida-Val, V.M.F. (Eds.), Biology of Tropical Fishes. INPA, Manaus, pp. $113-126$

Chippari-Gomes, A.R., 2002. Adaptações metabólicas dos ciclídeos aos ambientes hipóxicos da Amazônia. PhD Thesis, National Institute for Research in the Amazon (INPA), Brazil 151 pp.

Crampton, W.G.R., 1996. The electric fish of the upper Amazon: ecology and signal diversity. PhD Dissertation. University of Oxford, England, $223 \mathrm{pp}$.

Driedzic, W.R., Almeida-Val, V.M.F., 1996. Enzymes of cardiac energy metabolism in Amazonian teleosts and fresh-water stingray (Potamotrygon hystrix). J. Exp. Zool. 274, 327-333.

Driedzic, W.R., Phleger, C.F., Fields, J.H., French, C., 1978. Alterations in energy metabolism associated with the transition from water to airbreathing in fish. Can. J. Zool. 56, 730-735.

Hochachka, P.W., Somero, G.N., 1984. Biochemical Adaptation. Princeton University Press, Princeton.

Hochachka, P.W., Somero, G.N., 2002. Biochemical Adaptation: Mechanism and Process in Physiological Evolution. Oxford University Press.

Hochachka, P.W., Guppy, M., Guderley, H.E., Storey, K.B., 1978. Metabolic biochemistry of water vs. air-breathing fishes: muscle enzymes and ultrastructure. Can. J. Zool. 56, 736-750.

Hochachka, P.W., Land, S.C., Buck, L.T., 1997. Oxygen sensing and signal transduction in metabolic defense against hypoxia: lessons from vertebrate facultative anaerobles. Comp. Biochem. Physiol. 118A, 23-29.

Junk, W.J., 1980. Áreas inundáveis-um desafio para a limnologia. Acta Amazôn. 10, 775-796.

Junk, W.J., Soares, G.M., Carvalho, F.M., 1983. Distribution of fish species in a lake of the Amazon River floodplain near Manaus (Lago Camaleão), with special reference to extreme oxygen conditions. Amazoniana 7, 39-431.

Moon, T.W., Mommsen, T.P., 1987. Enzymes of intermediary metabolism in tissues of the little skate (Raja erinacea). J. Exp. Zool. 244, 9-15.

Muusze, B., Marcon, J.L., Van den Thillart, G., Almeida-Val, V.M.F., 1998. Hypoxia tolerance of Amazon fish-respirometry and energy metabolism of the cichlid (Astronotus ocellatus). Comp. Biochem. Physiol., A 120, $151-156$

Sidell, B.D., Driedzic, W.R., Stowe, D.B., Johnston, I.A., 1987. Biochemical correlations of power development and metabolic fuel preferenda in fish hearts. Physiol. Zool. 60, 221-232.

Singer, T.D., Ballantyne, J.S., 1989. Absence of extrahepatic lipid oxidation in a freshwater elasmobranch, the dwarf stingray (Potamotrygon magdalenae): evidence from enzyme activities. J. Exp. Zool. 251, $355-360$

Val, A.L., Almeida-Val, V.M.F., 1995. Fishes of the Amazon and their Environments. Physiological and Biochemical Features. Springer Verlag, Heidelberg.

Van den Thillart, G., Van Raaij, M., 1995. Endogenous fuels: non invasive versus invasive approaches. In: Hochachka, P.W., Mommsen, T. (Eds.), Biochemistry and Molecular Biology of Fishes, Environmental and Ecology Biochemistry, vol. 5. Elsevier, Amsterdam, pp. 33-63.

West, J.L., Bailey, J.R., Almeida-Val, V.M.F., Val, A.L., Sidel, B.D., Driedzic, W.R., 1999. Activity levels of enzymes of energy metabolism in heart and red muscle are higher in north-temperate-zone than in Amazonian teleosts. Can. J. Zool. 77, 690-696. 